\title{
2 What is Acting?
}

'Acting' invokes many synonyms: 'playing', 'pretending', 'impersonating', 'imitating', 'performing', 'representing'-to cite just a few. It is a term which is used in two contexts: there is the acting that is commonplace behaviour, occurring in everyday life and there is the acting that is an art, craft or body of skills practised by actors in theatre, radio, film and television. It is frequently-and incorrectly-assumed that the latter 'naturally' evolves from the former. This misconception is, to a degree, understandable since to act in both its everyday and its theatrical senses have existed sideby-side since their first recorded uses. In its everyday sense 'to act' ('to bring into action, bring about, produce, perform, work, make, do') was first cited in 1594 ('Act' $v$ Def. 2). This was the same year it was used in a theatrical sense: 'carry out or represent in mimic action (an ideal, incident, or story; to perform a play)' ('Act' $v$ Def.4). Undoubtedly, they are related, but it is misleading to consider them synonymous.

Ostensibly, acting as a craft or art is easily identified-we know it when we see itbut when it comes to definitions the term proves to be surprisingly slippery. Attempts to formulate a definition have been frustrated by the fact that there is no one acting, but multiple 'actings' or acting styles. Despite the current hegemony of psychological realism, Western acting praxis is today, as it has been historically, multifarious. There has never been one, universal acting style in the West. Meyerhold, Brecht, Artaud and Grotowski, for instance, all proposed a different acting for their theatres, and in the contemporary context, Robert Wilson's acting-slick, precise, virtuoso-is very different to the seeming anti-virtuosity of Forced Entertainment or the jarring bricolage of styles evident in the Wooster Group. But even though acting has been various and multivalent, it is generally accepted that common to all styles is one irreducible factor: impersonation. In Actors on Acting, Cole and Chinoy make the point: 'impersonation or the assumption of dramatic personality' is a prerequisite of all acting (Cole \& Chinoy, 1970).

However, as there are many acting styles, there are also multiple types of impersonation in Western theatre traditions. A heuristic continuum can be formulated with the 'actor-as-abstract' at one extreme, the 'actor-as-self' at the other, and significant coordinates along the axis:
Abstract--Type--Individuated
Type--Highly Individuated
Character--Multiple Personae--Self

\section{Actor-as-abstract:}

\footnotetext{
Actor is 'objectified' or represents 'one of the formal elements of a production', as in the works of Robert Wilson (Bishop, 1988). Other examples include: Maurice Maeterlinck’s actor-as-puppet, Gordon Craig's Über-marionette, Oskar Schlemmer's Tänzermensch, Tadeusz Kantor's mannequin.
} 


\section{Actor-as-type:}

Actor impersonates a conventional type or stock character. Examples can be found in commedia dell'arte, melodrama, pantomime.

\section{Actor-as-individuated type:}

Actor takes as basis for impersonation a social, historical, cultural or theatrical type and incorporates individual traits. Medieval Mystery plays, Restoration comedies, farce, and the theatre of Brecht provide examples of this.

\section{Actor-as-highly-individuated character:}

Actor's impersonation (re)presents a psychologically complex and motivated character. This is exemplified in Naturalism and its associated acting style psychological realism.

\section{Actor-as-multiple-personae:}

Actor's impersonation is comprised of multiple identities, a bricolage of personae. This composite might include various manifestations of the character and, possibly, the actor's 'self'. On playing John Proctor in LSD (...Just the High Points...), Willem Dafoe claims that he 'makes no distinction between being himself in the first part, playing John Proctor in the second, and playing himself (stoned) rehearsing John Proctor in the third' (Auslander, 1985).

\section{Actor-as-'self’:}

Associated with performance art and postmodern performance where the acting, to borrow Michael Kirby's term, is 'non-matrixed': the actor 'never behaves as if he were anyone other than himself. He never represents elements of character. He merely carries out certain actions' (Kirby, 2002).

Despite the existence of these different types of impersonation in the West, psychological realism dominates. In fact, in most current definitions, impersonation is conflated with the representation of a psychologically complex and highly individuated character. Acting is fundamentally:

- 'the art or practice of representing a character in a dramatic production' (The Penguin English Dictionary);

- 'the performing art in which an actor by means of movement, gesture and intonation attempts to realize a fictional character for the stage, for motion picture, and for television' (The New Encyclopaedia Britannica);

- 'the representation of a usually fictional character on stage or in films' (Columbia Encyclopedia). 
Put simply, acting = characterisation. In the words of Peter Thomson: we "now take it for granted that the relationship of actor to character is at the heart of the theatrical enterprise' (Thomson, 2000).

Well, isn’t it?

While we may find it difficult-almost impossible-not to view acting through the prism of character, character did not always occupy centre-stage, nor did it exhaust the actor's creative skills. It is timely to recall the etymology of acting: from the Latin actuary, 'acting' means a 'thing done': the actor is 'one who does things' (Zarrilli, 2002). William Worthen reinforces the point: 'to act is simply to do something, to express or create meaning through action (Greek: drama: an 'act' or 'deed)' (Worthen, 1984). However, over the last century and into the present, the doing has been increasingly sidelined, and character has assumed a privileged position. Acting has become primarily about character creation, marking a shift from doing to being, a pre-occupation with the embodiment of subjects over engaging in actions.

Yet it is important to remind ourselves that character has not always been foremost in acting because, quite simply, character itself is a modern concept. Thomson makes this point by way of anecdote: a 'successful young director (Jude Kelly) asked John Barton to define his attitude to character in Shakespeare's plays'. Barton replied that Shakespeare: 'would have associated the word 'character' with the formation of letters in writing or printing, not with invented creatures, not with people at all' (Thomson, 2000). Barton is not entirely accurate here: in Shakespeare's time 'character' was applied to a person's physical features, particularly in how they reflected their moral character ('Character' Def. 10): 'thou hast a mind that suits with this thy fair and outward character' (Twelfth Night 1. ii. 51). In the theatrical sense, however, 'character' was not used until the mid-seventeenth century: '[a] personality invested with distinctive attributes and qualities, by a novelist or dramatist; also, the personality or 'part' assumed by an actor' (OED 'Character' Def. 17.a). Impersonation in the sense of 'the dramatic representation of character' did not enter English until the early nineteenth century (OED 'Impersonation' Def. 2) and although its etymological predecessor personation was in use at the end of the sixteenth century, it did not mean characterisation. Edward Burns makes the point that on the Elizabethan stage to 'personate is to use the resources of one's person to present, not another being in the Stanislavskian sense [i.e. in the modern sense] but a thing done, action in this sense' (Burns, 1990). Moving forward in time, characterisation was not the object for eighteenth-century actors either. As Joseph Roach details in his excellent book The Player's Passion: studies in the science of acting, playing the passions was at the heart of acting-and, moreover, was what delighted audiences.

One must, then, be wary of the modern tendency to insert character where it has no place. This came home to me when I was recently re-reading Paradoxe sur le Comédien (The Paradox of Acting). A watershed work in acting theory, it has set the 
parameters of a debate which has been ongoing. Lee Strasberg claims that any 'discussion' of acting almost invariably touches on Diderot's famous paradox: to move the audience the actor must himself remain unmoved' (Strasberg, 1957). While the paradox is, indeed, very intriguing, it is not my primary concern here-rather, it is how character has crept into English translations of Paradoxe sur le Comédien. Take, for instance, the following excerpt from Walter Herries Pollock's late-nineteenth century, definitive English translation:

All the emotions he has given to you. The actor is tired, you are unhappy; he has had exertion without feeling, you feeling without exertion. Were it otherwise the player's lot would be the most wretched on earth: but he is not the person he represents [my emphasis] (Diderot, 1830/1957).

In the original, however, Diderot writes: 'mais il n'est pas le personnage' (Diderot, 1830/1922). Pollock has substituted 'person' for 'personnage', which may seem reasonable enough, except that for Diderot, personnage did not describe a 'person' (or, as is suggested here, 'character'). Consistent with common usage in his time, Diderot used personnage to denote certain moral and physical qualities extrapolated from an historical or eminent figure, the text, and from the actor's own imagination, and which the actor imitates. It is understandable how definitional slippage has at times occurred and the assumption made that Diderot must have been referring to character as we now use the term. For example, when he writes of the "character that you have to render'-'le caractère que tu avais à rendre'-it could be assumed as meaning 'theatrical character', but in keeping with its usage at the time, it would most certainly have referred here to a person's moral disposition and not the person or character per se. It is vital to recognize that in Diderot's time the French caractère and English 'character' stood for the moral qualities, multiple strands, as it were, which had not yet been woven into the integrated, singular personality or subject of our modern conception. The notion of character as a person or subject was to come later, in the mid-eighteenth century. However, even then, it is still not our modern theatrical sense of the word: rather, character remains an abstraction, an hypostatization, a metonym for moral actions: '[i]l désigne en particulier la manière d'être moral d'ou, par métonymie, les personnes envisagés sous l'angle de leur personnalité' ('caractère', 1992). It was the same in English: 'person regarded in the abstract as the possessor of specified qualities' (OED 'Character’ Def. 16a). The 'person' is only, if ever, envisaged through the moral traits he or she displays: they are primary. On the few occasions in Paradoxe where caractère does seem to denote the individual 'person', it in fact implies a 'type': 'toutes sortes de caractères' or 'caractères divers'. 'Types', which are more akin to Aristotle's concept of 'types of natural dispositions' that are 'drawn along the lines of the universal, not the individual' (Else, 1957).

Yet, character is so ingrained that it is difficult for us to conceive of acting without it at the centre. So, what happened? When and why did character assume centre 
stage-and how does the rise of character impact on how we think about the creativity of acting?

\subsection{Emergence and Rise of Character}

'it is the character that is the starting point of everything' Constant Coquelin (Cole \& Chinoy, 1970).

It is clear that, towards the end of the nineteenth century, acting was radically redefined first and foremost as characterisation. This trend toward a character-centric acting had been gradual. The eighteenth century preoccupation with the actor's skilful rendering of the passions remained significant in acting and its theories. William Archer, for example, claims that reproducing the physical effects of the so-called simple emotions 'must be the very groundwork of the actor's art' (Archer, 1888/1957). And by describing acting as the playing of passions, Tommaso Salvini (1829-1915), the greatly applauded actor of the nineteenth century, would not have been out of place on the eighteenth-century stage:

I felt the need of studying, not books alone, but men and things. [...] In short, all the passions for good and evil which have a root in human nature. I needed to study out the manner of rendering these passions (Cole \& Chinoy, 1970).

Salvini goes on, however, to describe a process which did not concern the eighteenthcentury actor:

I must become capable of identifying myself with one or another personage to such an extent as to lead the audience into the illusion that the real personage, and not a copy, is before them [my emphasis] (Cole \& Chinoy, 1970).

Over the course of the nineteenth century, the playing of the passions became subordinated to realizing character. George Henry Lewes claims that the actor should not merely present the emotions, but more specifically, 'the emotions of the character he is personating [...] the integrity of which is never sacrificed to isolated effects' (Lewes, 1875/1957). This is a crucial change. Whereas for Diderot the meticulous scoring of a rôle gave a performance cohesion and unity, now it relies on the 'integrity' or unity of a character. In the highly influential On Actors and the Art of Acting (1878), Lewes stresses this point: William Charles Macready, for example, lacked 'that sympathy with the character which would have given an impressive unity to his performanceit was a 'thing of threads and patches,' not a whole'. Charles Mathews, on the other hand, is commended for 'a certain artistic power of preserving the unity of character'. Moreover, what is clearly spelled out now is how this 'unity of character' is to be achieved: 'sympathy with the character'. This is the paradigmatic shift (one which 
occurred well before Stanislavsky turned it into a System): successful acting now relies on how closely actors sympathize and identify with their characters. Lewes praises the actress Eliza Felix Rachel for the way 'she thoroughly identified herself with the character'. Macready is redeemed by a performance in which he 'did not stand outside the character', but rather, 'felt himself to be the person, and having identified himself with the character' expressed 'what the character felt'. Although in Masks or Faces?, Archer does not subscribe to the possibility of total identification or transformation into character, he still uses the new terminology: 'incarnate in your personage', 'work myself into a character', 'putting on the character', 'entering into the skin of Tartuffe', 'to live in it'.

Searching for the factors behind this stellar rise of character, one finds three major influences:

\subsubsection{Romantic Dramatic Theory}

'between classicism and romanticism was a shift in general focus from plot to character' (Carlson, 1984).

In Theories of the Theatre, Marvin Carlson observes that English critics such as William Hazlitt (1788-1830) and the German Romantics shared 'an interest in character rather than actions as the central element of drama'. This trend toward privileging character was especially prevalent in the theorizing of Greek tragedy. Aristotle had not held the tragic hero or character (éthos) to be primary, but rather action (praxis). Elizabeth Belfiore (1992), Gerald Else (1957) and John Jones (1971) have conducted thorough rereadings of Aristotle's Poetics, to reveal 'that we have imported the tragic hero into the Poetics where the concept has no place' (Jones, 1971). The nineteenth-century Romantic theorists not only inserted the tragic hero where he or she never existed, but also focused on 'those parts of the Poetics which seemed to promise human and psychological interest' (Jones, 1971). Jones notes that Aristotle never mentions the tragic hero in the Poetics and, in fact, insists 'that Tragedy does not imitate human beings'. He quotes Aristotle: '[t]ragedy is an imitation not of human beings but of action and life' (Poetics 50a16). According to Belfiore, éthos never meant dramatic character in the Poetics, but was used to indicate either 'what kind of choice is made by an agent of a dramatic action' or 'as one of the six qualitative parts of a tragedy, second in importance to plot' (Belfiore, 1992).

Shakespeare is not exempt from this trend of prioritizing character. Indeed, it is by reference to Shakespeare that one can most readily trace how potent character became. Hazlitt, for example, views Shakespeare's major strength as his characterisation: in his view, Shakespeare was distinguished from his peers by his ability to create characters who were each 'as much itself, and as absolutely independent of the rest, as if they were living persons, not fictions of the mind' (Carlson, 1984). In fact, 
it would have been impossible for Shakespeare to think of character in this modern sense. Instead, as Burns claims, the Elizabethan character is best described in terms of 'pictures produced in action only momentarily', a claim supported, he argues, by the commonplace of devices such as 'allegorical vignettes', 'meta-theatrical presentations', disguise and cross-dressing (Burns, 1990). It might, in fact, be more accurate to view the Shakespearean character as discontinuous, a body of multiple, often conflicting dispositions-and ultimately determined by circumstances and events. Where the action goes, or needs to go, the character follows: the best way Rosalind can escape her uncle's court, survive in the world, and woo Orlando is to assume a male guise. Macbeth is explicit: 'Strange things I have in head, that will to hand;/ Which must be acted ere they may be scann'd' (Macbeth 3.iv. 138-39).

However, in the nineteenth century, the order is reversed: character becomes primary, the source of and key to action. Such characters even burst their fictional boundaries. In our contemporary context, the idea that characters can exist beyond the events of the play does not seem extraordinary; to ask the actor playing the part how many children has Lady Macbeth, for example, may seem entirely reasonablebut at the end of the nineteenth century, and even well into the twentieth, this was revolutionary. For the first time, it was presumed that 'each dramatic persona has life anterior and (if he survives the disease of the fifth act) posterior to the text' (Roach, 1985). Character biographies became not just of interest to the actors playing the part, but to the public. The popularity of works such as Mary Cowden Clarke's The Girlhood of Shakespeare's Heroines (1851-52) is evidence of this.

And if Romantic dramatic theory served to promote character to new heights, then the emerging aesthetic of Naturalism ensured that the task was completed.

\subsubsection{Naturalism}

'a man of flesh and bones on the stage, taken from reality, scientifically analyzed, without one lie’ Émile Zola (Cole \& Chinoy, 1970).

Zola's 'man of flesh and bones' was at the centre of the theatre of Naturalism. Otto Brahm, Naturalism's major exponent in Germany, is unequivocal: '[w]e no longer wish merely to play 'effective scenes' but rather wish to present complete characters with the whole conglomerate of qualities with which they are endowed' (Cole \& Chinoy, 1970). The agenda is articulated succinctly by Strindberg in his preface to Miss Julie. Here he outlines-from text to make-up-Naturalism's mission. Particularly noteworthy is the significance he places on character: most of the preface is, in fact, concerned with the question of character. Strindberg argues for a new concept of character for the stage-a character that does not represent 'an individual who has stopped developing, or who has moulded himself to a fixed role in life' (Strindberg, 1888/1976). In contrast to this, the new drama of Naturalism, according to Strind- 
berg, must contain characters that mirror 'how richly complex a human soul is'. To highlight this complexity, Strindberg plumbs the depths of the play's characters. No rock unturned, he lists, for example, 'the many possible motivations for Miss Julie's unhappy fate':

The passionate character of her mother; the upbringing misguidedly inflicted on her by her father; her own character; and the suggestive effect of her fiancé upon her weak and degenerate brain. Also, more immediately, the festive atmosphere of Midsummer Night; her father's absence; her menstruation; her association with animals; the intoxicating effect of the dance; the midsummer twilight; the powerfully aphrodisiac influence of the flowers; and finally, the chance that drove these two people together into a private room-plus of course the passion of the sexually inflamed man (Strindberg, 1888/1976).

And in the case of Jean, not content to stop at the present, Strindberg predicts his future:

So he survives the battle unharmed, and will quite possibly end as an hotelier; and even if he does not become a Rumanian [sic!] count, his son will probably get to university and very likely end up on the bench (Strindberg, 1888/1976).

In comparison, plot is given short shrift, just one paragraph, and even then it is subordinated to character. Strindberg claims that he has kept the plot of Miss Julie simple because:

I believe that what most interests people today is the psychological process. Our prying minds are not content merely with seeing something happen-they must know why it happens (Strindberg, 1888/1976).

In the words of John Galsworthy (1867-1933): 'a human being is the best plot there is' (Carlson, 1984).

This 'human being', the individual subject of everyday life and prototype for the new character of Naturalism, was itself a new conception-the product of emerging philosophical and scientific theories of the human body/mind which came under the disciplinary umbrella of Psychology.

\subsubsection{The Psychological Character}

' a network of endowments and limitations, themselves the complex product of heredity and environment' (Roach, 1985).

One should caution against conceiving of Psychology as a cohesive discourse, defined by a single set of theories, research methods, let alone agendas. Historically, it was more accurately a wide-ranging field of investigations conducted by individuals. The 
scope was broad: from Wilhelm Wundt's enterprise to establish a scientific, experimental psychology to Sigmund Freud's theories of the unconscious mind; Hermann Ebbinghaus's investigations on memory to Ivan Pavlov's work on conditioned reflexes. Yet despite this, common to all the research and its theories was a preoccupation with the individual and an assumption of its primacy. Burns makes the point that with the advent of modern Psychology in the nineteenth century 'forces and effects' previously conceived as 'impersonal' or 'interpersonal', become 'personal'-located in the mental states and processes of the individual (Burns, 1990). In a radical shift, the inner-world of the individual is prioritized and postulated as the source of and motivation for action. Raymond Williams observes that psychology and psychological assume the existence of:

a separable or at least radically distinguishable inner world, within which processes of feeling and relationship and activity can be described 'in their own terms', such processes often being taken as primary, with the outside world-nature or society-seen as secondary or contingent (Williams, 1976).

It is in this context that the actor William Charles Macready can redefine the player's art:

To fathom the depths of character, to trace its latent motives, to feel its finest quiverings of emotion, to comprehend the thoughts that are hidden under words, and thus possess one's self of the actual mind of the individual man (Cole \& Chinoy, 1970).

Inner motivations and hereditary factors are now seen as crucial to the shaping of the individual and the theatrical character. It is the subterranean world-the psychology of the character-which now becomes central both to the definition of acting and its creativity.

This new product of acting-the psychological character-required both a new acting and new theories of acting. Initially, the new directors attempted to resolve the problem pragmatically. In order to support the illusion of characters behaving naturally, actors should appear as if they are not actually acting. André Antoine, therefore, used with rare exception in his Théâtre-Libre productions amateur actors, who were not 'contaminated' by traditional actor training. Brahm, in a similar vein, called for 'human beings who find the emotions of the character to be represented from within and who express these with a simple natural voice' and without regard to the conventional gestures of 'stock types' (Cole \& Chinoy, 1970). Any hint of the theatrical should be underplayed or, even, eliminated. One radical way was to ignore the audience: one of the most controversial practices of the late nineteenth century was 'Antoine's Back', named after the common practice at the Théâtre-Libre of actors turning their backs on the audience. It caused quite a stir. In the words of Zola: this 'doesn't seem like much, but it is enormous for us in France' (Carlson, 1984). 
This denial of the presence of the audience was, in turn, further enabled by technological innovations, namely the introduction of gas lighting and limelight. While the 'intensity of limelight' virtually blinded actors, cutting them off from the audience, gas lighting in the auditorium could be dimmed, further obscuring the audience, and relegating them to the role of voyeurs (Mackintosh, 1993). These acting conventions and technical innovations all contributed to the enterprise of Naturalism, putatively convincing the audience that they were witnessing real people on the stage.

In practice, however, these new acting conventions were not always deemed successful. As an audience member, Lewes, for example, found 'Antoine's Back' untenable:

French actors, when not excellent, carry the reaction too far; and in the attempt to be natural forget the optique du thêâtre, and the demands of art. They will sit upon side sofas, and speak with their faces turned away from the audiences, so that half their words are lost (Lewes, 1875/1957).

But, while Lewes may have been disturbed by the extremes of this so-called natural acting, he was an integral part of the push for a new character-centric acting. Rather than merely impose a new set of theatrical conventions, Lewes and others realized that more fundamental changes were required.

\subsection{Being a Creative Actor}

The conventional artist 'cannot be the part, but he tries to act it' (Lewes, 1875/1957).

Among the nineteenth-century English theorists of theatre and acting, Lewes stands out. William Archer credited him as being the 'the most highly trained thinker who ever applied himself to the study of theatrical art in England' (Roach, 1985), and George Bernard Shaw is hyperbolic in his praise of Lewes as: 'the most able and brilliant critic between Hazlitt and our own contemporaries' (Carlson, 1984). Lewes had also been an actor, but it is for On Actors and the Art of Acting that he is primarily known. In the main, this work is a critical investigation of a number of eminent nineteenth-century English and European actors: Edmund Kean, Charles Kean, Eliza Felix Rachel, William Charles Macready, William Farren, Charles Mathews, Frédéric Lemaître, Mr and Mrs Keeley and Tommaso Salvini to name the most prominent. At a first glance, it may appear as superficial musings on acting by a Victorian theatre-enthusiast, but On Actors and the Art of Acting deserves a more attentive reading because it clearly articulates criteria for what came to be considered creative acting:

the success of the personation will depend upon the vividness of the actor's sympathy, and his honest reliance on the truth of his own individual expression, in preference to the conventional expressions which may be accepted on the stage. This is the great actor, the creative artist [my emphasis] (Lewes, 1875/1957). 
Lewes defines 'personation' as speaking ‘through the persona or character'; when the actor 'for the moment is what he represents'. This marks a modern use of the word, distinct from its earlier uses which, as we have seen, are associated with the embodiment of actions. Lewes then proceeds to identify what theorists and practitioners increasingly perceived as the major obstacle to this new, creative acting: the conventional, codified practices inherited from the previous century:

The majority have not learned to speak, much less to act; they mouth and gabble, look at the audience instead of their interlocutors, fling emphasis at random, mistake violence for emotion, grimace for humor, and express their feelings by signs as conventional and unlike nature as the gestures of a ballet-dancer. Good acting, on the contrary, like good writing, is remarkable for its individuality. It charms by its truth; and the truth is always original [my emphasis] (Lewes, 1875/1957).

This 'old' acting will no longer suffice; it is far too generalized and broad, not refined enough to realize the new characters of Naturalism, with all their complexities and idiosyncrasies: 'in modern drama we demand,' writes Lewes, 'the minute individualities of character'-a shift 'from the simple and general to the complex and individual'. In place, therefore, of conventional forms of expression, actors must draw upon their own 'inner' resources to create their own 'individual expression'. The actress Rachel epitomizes for Lewes this new hallmark of the actor's creativity:

Rachel personated, she spoke through the character, she suffered her inward feelings to express themselves in outward signs; she had not to cast about her for the outward signs which conventionally expressed such feelings. [...] Those few she personated, those she created [my emphasis] (Lewes, 1875/1957).

However, acting which depended on the actor's own original expression was not without its problems. It raised a number of intriguing questions for the theorist and, no doubt, pressing problems for the actor: 'How do I find the appropriate expression? By what standards will my own unique expression be measured? Will my audience 'get' my meaning?' Answers to these questions had to be found.

Directorial supervision was clearly one solution, and actors did increasingly rely on directors, who could tell them if their intentions were clearly manifested. Another obvious solution would be for actors to maintain an aesthetic distance so they could monitor their own acting. Actors had, after all, always done this to a greater or lesser extent. However, now this kind of distancing becomes problematic. The new ideal of acting, whereby actors identify with their characters, renders any aesthetic distance, any gap between actor and character undesirable. The ultimate solution for the problem of finding the appropriate expression was not to be found in encouraging gaps but, in fact, in the opposite: the actor's total identification with the character. Lewes suggests that if the actor 'personates', or 'is what he represents', then like the great Rachel, the appropriate feelings will express themselves. In short: it is believed 
that if the actor can thoroughly identify with the character, then all else will naturally follow. Coquelin writes:

If you have assimilated the essence of your personage, his exterior will follow quite naturally, and if there is any picturesqueness, it will come of itself. It is the mind which constructs the body (Cole \& Chinoy, 1970).

This movement toward individual expression marks a radical shift: what is natural, genuine and original is privileged-and acting, with its basis in convention, pretense and imitation, is made pejorative. It is not surprising, therefore, that Lewes should end up promoting being over acting. The conventional artist:

cannot be the part, but he tries to act it, and is thus necessarily driven to adopt those conventional means of expression with which the traditions of the stage abound. Instead of allowing a strong feeling to express itself through its natural signs, he seizes upon the conventional signs, either because in truth there is no strong feeling moving him, or because he is not artist enough to give it genuine expression (Lewes, 1875/1957).

Toward the end of the nineteenth century, being is the new ideal, one that has persisted, to varying degrees, in contemporary psychological realism. Lee Strasberg maintained that if 'you want to be an actor, don't act. Be' (Hornby, 1992). For actors to be, they must penetrate their own inner selves and assimilate the essence of their characters. Thus, acting becomes both character-centric and actor-centric, a double shift of focus which in turn, necessitates a completely new creative process.

Firstly, according to Coquelin, the actor 'must read the play carefully over many times, until he has grasped the intention of the author and the meaning of the character he is to represent' (Cole \& Chinoy, 1970). Actors have, of course, always studied their roles. Diderot, for example, praised the actress Clairon for doing precisely that. Her genius lay, according to Diderot, in her ability to choose a modèle idéal and score a rôle. The difference now is that, for the first time, the actor is called upon to make a psychological study of the text and his or her character. To recall Macready: to 'fathom the depths of character', 'trace its latent motives' and 'comprehend the thoughts that are hidden under words'.

Secondly, and crucially, the actor must identify with his or her character. This was the most important question that the nineteenth-century theorists and actors had to confront: 'how the interior life of the character and the interior life of the actor could somehow be brought together' (Roach, 1985). This was perceived as primarily a psychological problem, and if Psychology posed the problem, then it also provided the answers. Taking their lead from Psychology, acting theorists and critics made the assumption that inner processes are primary and affective. One of the most fundamental premises of psychology is that emotional reflexes and impulses proceed 'from interior to exterior, from subjective to objective: a psychic tremor stirs a physical act' (Roach, 1985). Acting theory and practice assumed that this flow from inner to outer 
could be profitably harnessed: through careful study and concentration, the appropriate feelings or thoughts could be induced, and it would then follow that the actor would produce quite naturally the right expression. To this end, Archer borrowed the concept of autosuggestion from Eduard von Hartmann's influential Philosophy of the Unconscious (1868), adopting the term to describe the 'mental concentration' that some actors utilize in helping them 'get into their character' (Archer, 1888/1957). Actor Wilson Barrett described this process to Archer:

I always endeavour to get a short time to myself, in my dressing room, to think over my character and work myself into it. [...] I have noticed the same thing in other actors (Archer, 1888/1957).

Autosuggestion is counter-balanced by the somatic process of innervation, which Archer derived from Charles Darwin's The Expression of Emotions in Man and Animals (1872). Archer uses the term innervation to describe Macready's practice of shaking a ladder offstage to achieve a required level of rage. In other words, a physical action, and not a mental frame of mind, is used to bring about the desired affect. Despite acknowledging its occurrence, Archer concludes that as 'a rule, however, mental concentration, rather than any physical device, is resorted to in order to overcome the difficulty of "striking twelve at once"' (Archer, 1888/1957).

A psychological working 'into' the character is never enough in itself: the actor has to produce the goods. Archer himself acknowledged that 'emotion alone, without the faculty of dramatic expression, will not make itself felt across the footlights'. Lewes wrote in a similar vein that it 'matters little what the actor feels; what he can express gives him distinctive value'. However, in the acting of psychological realism, an assumption of 'inner' to 'outer' is evident and prevalent to this day: Australian actor Bud Tingwell comments:

The most important thing I learnt was that if you understood the play to the point where you could think the thought processes of a character, everything would slot into place. [...] If you get inside the thought processes something else does take over. If your thinking is right then you shouldn't need to worry (Trengrove, 1991).

Another concept that acting borrowed from psychology was the subconscious. It would have been hard for acting theorists not to. Roach comments that by 'the 1870s the word unconscious and its physiological counterpart subconscious achieved popularity pervasive enough to constitute a fashion' (Roach, 1985). This newly conceived subconscious came to be perceived as the wellspring of the actor's creativity: the treasure trove which the actor only needed to unlock to be truly creative. The capability, however, to plumb one's inner creative source was not universal. There were some fortunate actors who possessed the right temperament, or in modern parlance, 'psychological make-up', to afford them easy access. Nineteenth-century actor Mr Bancroft acknowledges with some awe that Mrs Bancroft possessed 'nerves and muscles [which] sensitively respond to the touch' of her creative imagination (Archer, 
1888/1957). For those less fortunate, assistance was required. It became necessary, therefore, to provide theories which would explain how the actor could tap into their inner source of creativity and coax it out. This, of course, would become, in no small part, Stanislavsky's mission.

The monumental shift that took place in nineteenth-century acting, and continues to resonate today, was that it became in no small part-and fundamentally-a psychological process, an 'inner' process, eluding, at times, even the actors themselves. Archer comments that he 'could not reasonably expect' his 'obliging informants to study a disquisition on psychology' or 'to be accurately introspective of their experiences'. Describing himself as 'an amateur psychologist', Archer looked forward to a time when 'a better-equipped psychology may thread the maze [of mimetic emotion] to its innermost recesses'. It is apposite to recall that the full title of his work is Masks or Faces? A Study in the Psychology of Acting. It should also be noted that, beyond his theatre credentials, Lewes was also the author of The Problems of Life and Mind (1878). Although incomplete at his death, it was acclaimed for its penetration of, among other things, psychological issues. Lewes was, therefore, part of the emerging science of Psychology, whose influence on acting was so significant. Woe betides the actor who ignores 'the psychological conditions on which effects depend' for, in Lewes' view, he or she will 'pass into the artificial' (Lewes, 1875/1957).

Thus, towards the end of the nineteenth century, two emerging strands started to converge: acting moved toward the embodiment of a unique individual, and psychology moved towards subject-positions as the source of creativity. The weaving together of these strands would serve to reinforce the emerging character-centric acting and, in turn, would have enduring implications for the creativity of acting.

This is the trend which Stanislavsky inherited, followed and turned into what remains not only the hegemonic theory of stage acting in the West, but also the standard account of its creativity. 